\title{
Factors Affecting the Volatility of the Jakarta Composite Index before and after the Merger of Two Stock and Bond Markets in Indonesia
}

\author{
Hermanto Tanjung ${ }^{1}$, Hermanto Siregar ${ }^{1}$, Roy Sembel $^{1} \&$ Rita Nurmalina $^{1}$ \\ ${ }^{1}$ Business and Management Program, Bogor Agriculture University (IPB), Indonesia \\ Correspondence: Hermanto Tanjung, Business and Management Program, Bogor Agriculture University (IPB), \\ Indonesia. E-mail: sidihermanto@gmail.com
}

Received: June 19, 2014 Accepted: August 25, 2014 Online Published: October 30, 2014

doi:10.5539/ass.v10n22p91

URL: http://dx.doi.org/10.5539/ass.v10n22p91

\begin{abstract}
Relations in economies and finance are often simplified in the form of models. The Jakarta Composite Index (JCI) has relations to some variables of gold price, SBI (The Central Bank's Interest Rate), inflation, and GDP. The capital market in Indonesia has been growing to be a financial institution with strategic role in national economic development. Indonesia had ever had two capital markets: JSX (Jakarta Stock Exchange) and SSX (Surabaya Stock Exchange). Moreover, the two capital markets were merged to be BEI or IDX (Indonesia Stock Exchange) in 2008. With the merger, thus, there is only one capital market in Indonesia, i.e. BEI. The merger has implication to the management of capital market to stock trading liquidity and factors influencing the Indonesia Stock Exchange (IDX) Compose Price Index (IHSG). From the consideration, the research problem is how the impact of capital market merger to factors influencing the Indonesia Stock Exchange (IDX) Compose Price Index. The dissertation research has goal of analyzing effects of the gold price, SBI, inflation and GDP on JCI before and after the merger and formulating the consequences of the impact of the merger policy. The data of the variables used in this research are monthly time series for the period 2004(1) to 2012(12). Autocorrelation and heteroscedasticity problem persist in the initial model. To overcome these problems, the model was developed by using the ARCH/GARCH method. This model is expected to be useful to predict and make decisions related to volatility of the JCI and the affecting factors.
\end{abstract}

Keywords: ARCH/GARCH, autocorrelation, heteroscedasticity, Jakarta composite index, merger

\section{Background}

Capital markets have an important role in allocating funds for investment. The crucial role of capital markets is to bring capital owners and capital requesters. The capital market is one of the most strategic areas of finance that can move all kinds of economic activities and contribute to the national development (Tease, 1993). The existence and development of the stock market does not exist by itself due to economic factors influencing each other and reciprocity.

Initially, there were two stock and bond markets in Indonesia i.e. JSX (Jakarta Stock Exchange) and SSX (Surabaya Stock Exchange). In late December 2007, the Government made a policy to combine the two markets into the Indonesia Stock Exchange (ISX). The policy of the merger has implications for stock trading liquidity, financial ratio performance of ISX and organization. One important issue in the stock markets is volatility of JCI; and JCI as the price concept is often influenced by several variables including gold price, SBI, inflation, and GDP.

Relations in the economy and finance are very complex since their nature can be either unidirectional or reciprocal like the relationship of JCI with other factors. For the purposes of analysis and policy, the complex economic relations can be simplified in order to make it easier in the processes of reading, analyzing, inferring and making decisions. These relationships are the relationships between the dependent variables and independent variables. In this study, JCI was categorized as a dependent variable and the other factors i.e. the gold price, SBI, inflation and GDP categorized as independent variables.

The relationships can be represented in the form of an econometric model describing effects of the independent variables on the dependent variables. The model can be analyzed to make decisions regarding volatility of the JCI and the associated variables. 


\section{Research Questions}

1) How do the gold price, SBI, inflation and GDP influence JCI before and after the merger of the two stocks and bond markets into ISX?

2) What are implications of the merger of JSX and SSX into ISX?

\section{Research Objectives}

1) Analyzing effects of the gold price, SBI, inflation and GDP on JCI before and after the merger of the two stocks and bond markets into ISX.

2) Formulating consequences of the merger policy of the two markets.

\section{Data and Methodology}

Data used in this study were time series, with the time period from 2004 to 2012 i.e. for nine years, where each year has twelve months, and as a whole it was amounted to 108 monthly observations. The monthly data were collected including JCI, the gold price, SBI, inflation, and the GDP. Sources of data were derived from financial statements of BEI, BI and BPS. Since the GDP is quarterly, this variable is made monthly by using a simple interpolation.

In the data analysis, the data were classified according to two periods, namely; the period before the merger (2004-2007) and the period after the merger (2008-2012) which were initially modeled by using the multiple regression analysis (Gujarati, 2003; Maddala, 2005; Greene, 2012). If autocorrelation and heteroscedasticity problems persisted in the initial model, the ARCH and GARCH methodology will be employed (Enders, 2004; Verbeeck, 2004; Tsay, 2005). The framework of this study is presented in Figure 1 as follows.

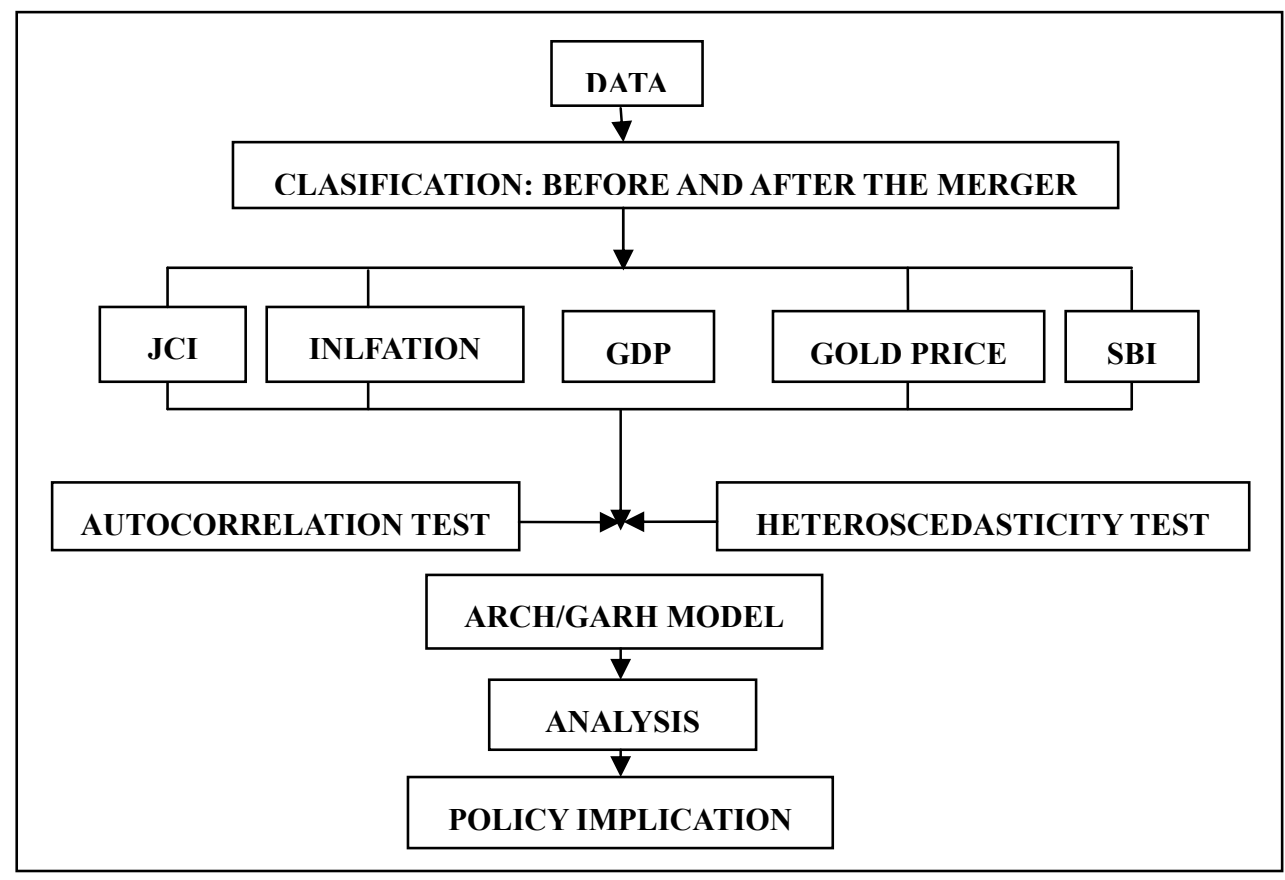

Figure 1. The study framework

The initial multiple regression models in this study is as follows where INFLASI is inflation, PDB is the GDP, EMAS is gold price, SBI is the Central Bank's Interest Rate, and $\mu_{t}$ is the error term.

$$
\boldsymbol{J C I}_{t}=\beta_{0}+\beta_{1} \boldsymbol{I N F L A S I} \boldsymbol{I}_{t}+\beta_{2} \boldsymbol{P D B}_{t}+\beta_{3} \boldsymbol{E M A S}_{t}+\beta_{4} \boldsymbol{S B I} \boldsymbol{I}_{t}+\mu_{t}
$$

In the $\mathrm{ARCH} / \mathrm{GARCH}$ methodology this relation can be written as follows:

$$
J C I_{t}=\mathrm{b}_{0}+\sum \mathrm{b}_{\mathrm{i}} \mathrm{x}_{\mathrm{it}}+\mathrm{e}_{\mathrm{t}} \text { and } \sigma_{\mathrm{t}}^{2}=\alpha_{0}+\alpha_{1} \mathrm{e}_{\mathrm{t}-1}^{2}+\lambda \alpha^{2} \mathrm{t}-1
$$

Where $b_{i}$ is regression coefficient of the $i^{\text {th }}$ independent variable $\left(\mathrm{x}_{\mathrm{it}}\right) . \mathrm{x}_{\mathrm{it}}$ is the independent variable and $\mathrm{e}_{\mathrm{t}}$ is the error term.

In this research, the models formed include 1) the model before merger and 2) the model after the merger. 


\section{Results and Discussions}

\subsection{The Model before the Merger}

This model is based on the monthly data of JCI, gold price, SBI, inflation and GDP for the period of 2004-2007, i.e. 48 months as the research object before the merger of SSX and JSX is carried out. Moreover, the data are carried out through autocorrelation and heteroscedasticity tests. Moreover, it is followed with the search of the best model through the ARCH/GARCH test.

The first step is to see the initial regression among JCI and gold price, SBI, inflation, GDP, by making use of the OLS method. The initial multiple regressions are as follows:

Table 1. Regression result before merger

\begin{tabular}{|c|c|c|c|c|}
\hline \multicolumn{5}{|c|}{ Dependent Variable: IHSG } \\
\hline \multicolumn{5}{|l|}{ Method: Least Squares } \\
\hline \multicolumn{5}{|c|}{ Sample: 2004M01 2007M12 } \\
\hline \multicolumn{5}{|c|}{ Included observations: 48} \\
\hline Variable & Coefficient & Std. Error & t-Statistic & Prob. \\
\hline$\overline{\mathrm{C}}$ & -2787.022 & 452.7145 & -6.156246 & 0.0000 \\
\hline INFLASI & 35.12824 & 15.53044 & 2.261895 & 0.0288 \\
\hline PDB & 0.023375 & 0.004528 & 5.162225 & 0.0000 \\
\hline HARGA EMAS & 2.739775 & 0.380082 & 7.208378 & 0.0000 \\
\hline SBI & -59.79593 & 8.735306 & -6.845316 & 0.0000 \\
\hline R-squared & 0.954259 & \multicolumn{2}{|c|}{ Mean dependent var } & 1387.336 \\
\hline Adjusted R-squared & 0.950004 & \multicolumn{2}{|c|}{ S.D. dependent var } & 568.2781 \\
\hline S.E. of regression & 127.0662 & \multicolumn{2}{|c|}{ Akaike info criterion } & 12.62563 \\
\hline Sum squared resid & 694269.7 & \multicolumn{2}{|c|}{ Schwarz criterion } & 12.82054 \\
\hline Log likelihood & -298.0150 & \multicolumn{2}{|c|}{ Hannan-Quinn criter. } & 12.69928 \\
\hline F-statistic & 224.2673 & \multicolumn{2}{|c|}{ Durbin-Watson stat } & 0.973456 \\
\hline
\end{tabular}

Table 2. ARCH (1) Regression result before merger

Dependent Variable: IHSG

Method: ML - ARCH (Marquardt) - Normal distribution

Sample: 2004M01 2007M12

Included observations: 48

$\mathrm{GARCH}=\mathrm{C}(6)+\mathrm{C}(7)^{*} \operatorname{RESID}(-1)^{\wedge} 2$

\begin{tabular}{lllll} 
Variable & Coefficient & Std. Error & Z-Statistic & Prob. \\
\hline C & -3140.988 & 585.3501 & -5.366000 & 0.0000 \\
INFLASI & 28.75255 & 27.10776 & 1.060676 & 0.2888 \\
PDB & 0.027130 & 0.005389 & 5.034575 & 0.0000 \\
HARGA EMAS & 2.312658 & 0.392672 & 5.889541 & 0.0000 \\
SBI & -51.98403 & 8.658645 & -6.003714 & 0.0000 \\
Variance Equation & & & \\
C & 10452.71 & 2975.574 & 3.512839 & 0.0004 \\
RESID(-1)^2 & 0.326032 & 0.371804 & 0.876892 & 0.3805 \\
R-squared & 0.952131 & Mean dependent var & 1387.336 \\
Adjusted R-squared & 0.945126 & S.D. dependent var & 568.2781 \\
F-statistic & 135.9178 & Durbin-Watson stat & 0.842012
\end{tabular}


It can be seen that all of the independent variables have significant effects on JCI because p-value smaller than $\alpha$ $=5 \%$. The second step is to identify the existence of autocorrelation and heteroscedasticity problems by using the White tests. That is: the Obs*R-squared result $=4.61 \%$, which is smaller than $\alpha=5 \%$, thus the data has autocorrelation and heteroscedasticity problems. Furthermore, the third step is to do test of six-phase ARCH/GARCH effects i.e.; ARCH (1), ARCH/GARCH $(1,1)$, ARCH/GARCH $(2,1)$, ARCH/GARCH $(2,2)$, $\mathrm{ARCH} / \mathrm{GARCH}(3,2), \mathrm{ARCH} / \mathrm{GARCH}(4,2)$. It is urgent because it solves the autocorrelation and heteroscedasticity problems. The method is to find the best model. Systematically the analysis is as follows:

\section{ARCH (1)}

After the analysis to the initial equation is carried out where the equation contains autocorrelation and heteroscedasticity problems, the next analysis is carried out to the ARCH/GARCH test. The first test is related to ARCH (1), and the results are as in Table 2.

From the above results, it is seen that the residual square elements are significant in the variance equation as shown in ARCH (1) with the results of RESID $(-1)^{\wedge} 2 p$-value of $38.05 \%$, which is much greater than $\alpha=5 \%$, indicating the model does not contain the autocorrelation and heteroscedasticity problems. Furthermore, $R^{2}$ is $95.21 \%$, a very large value, it can be interpreted that the independent variables are very determinant toward JCI or INFLASI, PDB, HARGA EMAS, and SBI variables which can explain the JCI phenomenon. However, the ARCH (1) model is not enough to be used as the best model because INFLASI does not significantly affecting JCI. Thus, the analysis is carried out in the next ARCH/GARCH test.

In the same way, the test is carried out to ARCH/GARCH effect, i.e.; ARCH/GARCH $(1,1)$, GARCH $(2,1)$, ARCH/GARCH $(2,2), \operatorname{ARCH} / \operatorname{GARCH}(3,2)$ and ARCH/GARCH $(4,2)$.

The fourth step is to find the best model. After the trial tests are carried out to ARCH/GARCH by considering p-value and $R^{2}$ in each ARCH/GARCH, it finds the best model of GARCH $(4,2)$. The result can be observed in Table 3.

Table 3. GARCH $(4,2)$ Regression result before merger

\begin{tabular}{|c|c|c|c|c|}
\hline \multicolumn{5}{|c|}{ Dependent Variable: IHSG } \\
\hline \multicolumn{5}{|c|}{ Method: ML - ARCH (Marquardt) - Normal distribution } \\
\hline \multicolumn{5}{|c|}{ Sample: 2004M01 2007M12 } \\
\hline \multicolumn{5}{|c|}{ Included observations: 48} \\
\hline \multicolumn{5}{|c|}{$\begin{array}{l}\mathrm{GARCH}=\mathrm{C}(6)+\mathrm{C}(7)^{*} \operatorname{RESID}(-1)^{\wedge} 2+\mathrm{C}(8)^{*} \operatorname{RESID}(-2)^{\wedge} 2+\mathrm{C}(9) * \operatorname{RESID}(-3)^{\wedge} 2+\mathrm{C}(10)^{*} \operatorname{RESID}(-4)^{\wedge} 2+ \\
\mathrm{C}(11)^{*} \operatorname{GARCH}(-1)+\mathrm{C}(12)^{*} \operatorname{GARCH}(-2)\end{array}$} \\
\hline Variable & Coefficient & Std. Error & z-Statistic & Prob. \\
\hline$\overline{\mathrm{C}}$ & -2787.057 & 522.1576 & -5.337578 & 0.0000 \\
\hline INFLASI & 35.72411 & 16.59361 & 2.152883 & 0.0313 \\
\hline PDB & 0.023763 & 0.005059 & 4.697273 & 0.0000 \\
\hline HARGA EMAS & 2.694231 & 0.442084 & 6.094383 & 0.0000 \\
\hline SBI & -59.84383 & 8.801931 & -6.798943 & 0.0000 \\
\hline \multicolumn{5}{|l|}{ Variance Equation } \\
\hline $\mathrm{C}$ & 10606.90 & 13990.08 & 0.758173 & 0.4483 \\
\hline $\operatorname{RESID}(-4)^{\wedge} 2$ & -0.049936 & 0.543263 & -0.091919 & 0.9268 \\
\hline GARCH(-2) & -0.366333 & 1.278685 & -0.286492 & 0.7745 \\
\hline R-squared & 0.951571 & \multicolumn{2}{|c|}{ Mean dependent var } & 1387.336 \\
\hline Adjusted R-squared & 0.936773 & \multicolumn{2}{|c|}{ S.D. dependent var } & 568.2781 \\
\hline S.E. of regression & 142.8929 & \multicolumn{2}{|c|}{ Akaike info criterion } & 12.74388 \\
\hline F-statistic & 64.30530 & \multicolumn{2}{|c|}{ Durbin-Watson stat } & 0.920354 \\
\hline
\end{tabular}

From the above table, it is seen that the residual square elements are significant in the variance equation as shown by ARCH (4) generating RESID (-1)^2 p-value of $92.68 \%$, and GARCH (2) $77.45 \%$, which is greater than $\alpha=5 \%$, indicating the model has no autocorrelation and heteroscedasticity problems. All independent variables in the model are significant as they have p-values smaller than $\alpha=5 \%$. Furthermore, $R^{2}$ is $95.16 \%$, 
which can be meant that the independent variables are very determinant toward JCI.

In the analysis, the best model for "before the merger" in Table 3 is GARCH $(4,2)$ :

$$
\begin{gathered}
I H S G=-2787.057+35.72411 \text { INFLASI+0,02376PDB+2.69423EMAS-59.84383SBI } \\
\text { GARCH }=10606.90-0,0499 e_{(t-4)}^{2} 0.3663 \text { GARCH }_{(t-2)}
\end{gathered}
$$

\subsection{The Model after the Merger}

In the situation "After the merger", the model is based on the period of 2008-2012, i.e. 60 months. As before, the autocorrelation and heteroscedasticity tests are performed, and then it is followed with the search of the best model through the ARCH/GARCH tests.

The first step is to search the initial regression among JCI and gold price, SBI, inflation, GDP, with OLS method, the initial multiple regression is as follows.

\begin{tabular}{|c|c|c|c|c|}
\hline \multicolumn{5}{|c|}{ Dependent Variable: IHSG } \\
\hline \multicolumn{5}{|c|}{ Method: Least Squares } \\
\hline \multicolumn{5}{|c|}{ Sample: 2008M01 2012M12 } \\
\hline \multicolumn{5}{|c|}{ Included observations: 60} \\
\hline Variable & Coefficient & Std. Error & t-Statistic & Prob. \\
\hline$\overline{\mathrm{C}}$ & -904.9287 & 791.1729 & -1.143781 & 0.2577 \\
\hline INFLASI & 39.58744 & 32.24938 & 1.227541 & 0.2248 \\
\hline PDB & 0.011320 & 0.007906 & 1.431733 & 0.1579 \\
\hline HARGA EMAS & 2.361463 & 0.592779 & 3.983716 & 0.0002 \\
\hline SBI & -68.81994 & 18.00672 & -3.821903 & 0.0003 \\
\hline R-squared & 0.809583 & \multicolumn{2}{|c|}{ Mean dependent var } & 1527.387 \\
\hline Adjusted R-squared & 0.795735 & \multicolumn{2}{|c|}{ S.D. dependent var } & 624.5249 \\
\hline S.E. of regression & 282.2586 & \multicolumn{2}{|c|}{ Akaike info criterion } & 14.20318 \\
\hline F-statistic & 58.46000 & \multicolumn{2}{|c|}{ Durbin-Watson stat } & 0.275780 \\
\hline
\end{tabular}

Table 4. Regression result after merger

Table 5. ARCH (1) Regression result after merger

Dependent Variable: IHSG

Method: ML - ARCH (Marquardt) - Normal distribution

Sample: 2008M01 2012M12

Included observations: 60

$\mathrm{GARCH}=\mathrm{C}(6)+\mathrm{C}(7)^{*} \operatorname{RESID}(-1)^{\wedge} 2$

\begin{tabular}{lllll} 
Variable & Coefficient & Std. Error & Z-Statistic & Prob. \\
\hline $\mathrm{C}$ & -2905.167 & 505.9546 & -5.741952 & 0.0000 \\
INFLASI & 14.61767 & 45.54361 & 0.320960 & 0.7482 \\
PDB & 0.026207 & 0.004436 & 5.907241 & 0.0000 \\
EMAS & 1.800503 & 0.310094 & 5.806309 & 0.0000 \\
SBI & -36.09435 & 9.457316 & -3.816553 & 0.0001 \\
Variance Equation & & & \\
$\mathrm{C}$ & 10035.08 & 5611.867 & 1.788190 & 0.0737 \\
RESID(-1)^2 & 1.126369 & 0.631602 & 1.783353 & 0.0745 \\
R-squared & 0.742799 & Mean dependent var & 1527.387 \\
Adjusted R-squared & 0.713682 & S.D. dependent var & 624.5249 \\
F-statistic & 25.51072 & Durbin-Watson stat & 0.186100 \\
\hline
\end{tabular}

It is seen that INFLASI and PDB variables are not significant affecting JCI where p-values are tremendously larger than $\alpha=5 \%$. The variables of HARGA EMAS and SBI are significant to JCI as the p-values are smaller 
than $\alpha=5 \%$. The second step is to identify the presence of autocorrelation and heteroscedasticity by using the White tests. The results are: Obs*R-squared $=0.37 \%$, the value is smaller than $\alpha=5 \%$ so the data has autocorrelation and heteroscedasticity problems. Furthermore, the next step is to do trial test of six-phase ARCH/GARCH effect i.e. ARCH (1), ARCH/GARCH $(1,1), \operatorname{ARCH/GARCH~}(2,1), \operatorname{ARCH/GARCH}(2,2)$, ARCH/GARCH $(3,2)$, ARCH/GARCH $(4,2)$. This is urgent in order to solve for the autocorrelation and heteroscedasticity problems. The method is to find the best model. Systematically the analysis is as follows:

\section{ARCH (1)}

The first test is carried out for the ARCH (1) model and the results are as follows in Table 5.

From the above results, it is seen that the residual square elements are not significant in the variance equation as shown in ARCH (1) generating RESID (-1)^2 p-value of 7.45\%, which is tremendously greater than $\alpha=5 \%$, indicating the model does not contain autocorrelation and heteroscedaticity problems. Furthermore, $R^{2}$ is $74.27 \%$; this value is great so it is interpreted that the independent variables are determinant toward JCI or INFLASI, PDB, HARGA EMAS, and SBI variables which can explain the JCI volatility. However, the ARCH (1) model cannot be enough to be the best model because there is one independent variable which is insignificant INFLASI.

In the same way, the test are carried out for ARCH/GARCH effect, i.e. ARCH/GARCH $(1,1)$, GARCH $(2,1)$, ARCH/GARCH $(2,2), \operatorname{ARCH} / \operatorname{GARCH}(3,2)$ and $\mathrm{ARCH} / \mathrm{GARCH}(4,2)$.

The fourth step is to find the best model. After conducting the tests, by considering p-values and $R^{2}$ from each $\mathrm{ARCH} / \mathrm{GARCH}$, we get the best model, i.e. GARCH $(4,2)$. The results are in Table 6 as follows.

Table 6. GARCH $(4,2)$ Regression result after merger

Dependent Variable: IHSG

Method: ML - ARCH (Marquardt) - Normal distribution

Sample: 2008M01 2012M12

Included observations: 60

$\mathrm{GARCH}=\mathrm{C}(6)+\mathrm{C}(7) * \operatorname{RESID}(-1)^{\wedge} 2+\mathrm{C}(8)^{*} \operatorname{RESID}(-2)^{\wedge} 2+\mathrm{C}(9)^{*} \operatorname{RESID}(-3)^{\wedge} 2+\mathrm{C}(10) * \operatorname{RESID}(-4)^{\wedge} 2+$ $\mathrm{C}(11) * \mathrm{GARCH}(-1)+\mathrm{C}(12) * \mathrm{GARCH}(-2)$

\begin{tabular}{lllll} 
Variable & Coefficient & Std. Error & z-Statistic & Prob. \\
\hline C & -906.1256 & 594.4960 & -1.524191 & 0.1275 \\
INFLASI & 42.43096 & 11.11500 & 3.817451 & 0.0001 \\
PDB & 0.011013 & 0.005479 & 2.010125 & 0.0444 \\
EMAS & 2.346951 & 0.355748 & 6.597231 & 0.0000 \\
SBI & -60.89876 & 9.951004 & -6.119861 & 0.0000 \\
Variance Equation & & & & \\
C & 53555.87 & 53761.20 & 0.996181 & 0.3192 \\
RESID(-4)^2 & 0.180327 & 0.254061 & 0.709776 & 0.4778 \\
GARCH(-2) & -0.955782 & 0.110612 & -8.640892 & 0.0000 \\
R-squared & 0.807380 & Mean dependent var & 1527.387 \\
Adjusted R-squared & 0.763237 & S.D. dependent var & 624.5249 \\
S.E. of regression & 303.8830 & Akaike info criterion & 13.71813 \\
F-statistic & 18.29043 & Durbin-Watson stat & 0.275899 \\
\hline
\end{tabular}

From the above table, it is seen that the residual square elements are significant in the variance equation as shown in ARCH(4) with the results of RESID (-1)^2 p-value totaling 47.78\%, which is tremendously greater than $\alpha=5 \%$, and $\operatorname{GARCH}(2)$ is zero percent. This suggests the absence of autocorrelation and heteroscedasticity problems. All independent variables in the model has p-value smaller than $\alpha=5 \%$. Furthermore, $R^{2}$ is $80.74 \%$, the value is great so it can be interpreted that the independent variables are very determinant toward JCI or INFLASI, PDB, HARGA EMAS, and SBI variables can explain the JCI volatility.

The best model in Table 6 GARCH $(4,2)$ is for "before the merger" can be written as follows: 


$$
\begin{array}{r}
I H S G=-906.126+42.43096 I N F L A S I+0,01101 P D B+2.34695 E M A S-60.89876 S B I \\
G A R C H=53555.87+0.1803 e_{(t-4)}^{2}-0.9558 \text { GARCH }_{(t-2)}
\end{array}
$$

\subsection{Comparison before and after Merger}

From the analysis of ARCH/GARCH, it can be carried out the comparison of model for before and after the merger as follows.

From the Table it is found the similarity of the best model. Both models can be specified using the GARCH $(4,2)$.

The difference of the model is seen in $R^{2}$, and p-values. The $R^{2}$ before the merger is $95.57 \%$, which is higher than after the merger $(80.74 \%)$. It indicates that determination of independent variables to JCI before merger is stronger when compared to that after merger. This situation may indicate that after the merger, the predictability of JCI has been lower.

\begin{tabular}{|c|c|c|c|c|}
\hline Condition & The Best Model & $R^{2}$ Percent & p-value Model & p-value Variance equation \\
\hline \multirow{4}{*}{ Before merger } & \multirow{4}{*}{$\operatorname{GARCH}(4,2)$} & \multirow{4}{*}{$95.57 \%$} & INFLASI: 0.0313 & \\
\hline & & & PDB : 0.0000 & $\operatorname{Resid}(-1)^{\wedge} 2=0.9268$ \\
\hline & & & H EMAS:0.0000 & $\operatorname{GARCH}(4,2)=0.7745$ \\
\hline & & & SBI: 0.0000 & \\
\hline \multirow{4}{*}{ After merger } & \multirow{4}{*}{$\operatorname{GARCH}(4,2)$} & \multirow{4}{*}{$80.74 \%$. } & INFLASI:0.0001 & \\
\hline & & & PDB: 0.0444 & $\operatorname{Resid}(-1)^{\wedge} 2=0.4778$ \\
\hline & & & H EMAS:0.0000 & $\operatorname{GARCH}(4,2)=0.0000$ \\
\hline & & & SBI: 0.0000 & \\
\hline
\end{tabular}

Table 7. Comparing the best models for "before" and "after" the merger

\section{Discussion}

Based on the statistical data during the period of 2008-2012, particularly after the merger of the two stocks and bond markets, the real sector has developed rapidly. It happens that JCI tends to decrease after the merger. Therefore, the investments have changed from the stock or bond sector to the real sector. Appropriate to the decline in JCI, real sector particularly property sector grows fast in Indonesia.

After the merger particularly in the early years after the merger, the gold price went down, but after that it rose again by 2012. It is shown that the gold price tends to rise every month regularly, and sometimes it goes down. However, the fluctuations of gold price tend to rise after the merger.

The SBI rate has risen after the merger. In the first years after the merger, SBI grew very high totaling $11.90 \%$, and the high interest rate of SBI is in an effort to compensate for the high rate of inflation. Moreover, in current economic condition, whereby SBI is still considered relatively high, there is a strong reason for fund allocation into savings.

Similarly, the property sector is more stable and tends to go up every month, and this becomes a lucrative investment option. However, it is different from stock or bond investment where stock or bond prices are likely to fluctuate in the extreme and risky way, but it has a high profit prospect, and the risk of loss that will always be a threat to investors only happens once.

Towards the end of the merger in 2007, the price of gold tended to rise. SBI initially rose, and fell, but finally it is stabilized. Inflation fluctuates greatly. Meanwhile, in the same time, JCI movement fluctuates. These three factors (gold, SBI and inflation) and GDP (as a proxy of property) are situations which become a factor affecting the business environment of JCI.

The factors affecting JCI in this study are all factors that are domestic. The analysis did not include how far the influence of the international factors on the development of JCI. This is particularly important since foreign investors invest their funds in stocks in Indonesia in quite large amounts estimated at approximately $60 \%$. This will give an impact on the investment allocation diversion since foreign investors play a more dominant role in international capital stocks. Thus, the international factor becomes very important in the analysis of JCI.

Since there is a relationship between the international factor and the development of JCI, the analysis requires 
considering international indicators. In this case, the U.S. dollar exchange rate and international stocks like Don Jowns, Han Seng and others should be considered. The international indicators are very sensitive to the development of JCI. If the movement of JCI is not profitable due to the development of security and noneconomic activities, it will have an impact on the diversion of investment which moves toward capital flight.

Because this study did not include the international elements and focused more on domestic factors, the discussions of the research results illustrate the behaviors of domestic indicators. With the limitations in this analysis, it is expected that further researches incorporating elements of international indicators into the model will be conducted.

Frequently, foreign investors also pay attention to service organizations, since the merger of JSX and SSX into ISX, ISX has to pay higher costs due to the construction of the information network of Jakarta Automatic Trading System (JATS). This results in higher fees for the transactions of stocks in ISX. When compared to the international capital markets such as in India, the transaction fees in ISX are much higher, and this can be a trigger which causes foreign investors to be less interested in investing their funds in Indonesia.

\section{Conclusion and Recommendations}

Based on the results of this research, it is concluded that the influence of INFLASI, PDB, HARGA EMAS and SBI variables to JCI is very significant both before and after the merger. However, in the analysis it is found that the influence of INFLASI is less significant to JCI before the merger. On the other hand, PDB after merger is less significant to JCI as compared to before the merger. After the merger, JCI tended to decrease significantly if compared to that before the merger. From the discussion, it is suggested that:

1) The regulators should be carrying out reviews to legislations and regulations on the administration of the capital market; so as to make it becomes more efficient.

2) The operators should improve and strengthen the organization of ISX and optimize JATS as well as to develop more stock exchange corner programs in each university campus.

3) Investors and potential investors should pay attention to the consequences of variables that have significant influences to JCI particularly by observing INFLASI, gold price, SBI, and GDP in the effort of optimizing fund allocation.

4) For any limitation of not using the international indicators, further researches should be carried out to analyze effects of international variables on JCI, and establish strategies for optimizing functions and roles of the ISX.

\section{References}

Andrade, G., Mitchell, M., \& Stafford, E. (2001). New evidence and perspectives on mergers. Journal of Economic Perspective, 15(2), 103-120. http://dx.doi.org/10.1257/jep.15.2.103

Bekaert, G., Harvey, C. R., \& Lundblad, C. T. (2003). Equity Market liberalization in emerging markets. The Journal of Financial Research, XXVI(3), 275-299. http://dx.doi.org/10.1111/1475-6803.00059

Bodie, Z., Robert, C. M., \& Cleeton, D. L. (2009). Financial Economics. New Jersey; Person Prentice Hall.

Bratton, W. W. (2005). The New Dividend Puzzle. Georgetown Law Journal, 93(3), 845.

Cooper, D. R., \& Schindler, P. S. (2008). Business Research Methods. New York: Mc-Graw Hill.

Cuthbertson, K. (1996). Quantitative financial economics; stocks, bonds and foreign exchange. John Wiley and Sons. United States of America.

Enders, W. (2004). Applied econometric time series. John Wiley and Son. United States of America.

Fama, E. F. (1970). Efficient capital markets; a review of theory and empirical works. The Journal of Finance, 25(2), 383-417. Papers and Proceedings of the Twenty-Eighth Annual Meeting of the American Finance Association New York, N.Y. Published by: Blackwell Publishing for the American Finance Association. http://dx.doi.org/10.2307/2325486

Greene, W. H. (2012). Econometric analysis. Pearson Educated Limited. United States of America.

Gujarati, D. N. (2003). Basic econometric. McGraw Hill. New York.

Maddala, G. S. (2005). Introduction to economics. John Wiley and Son. West Sussex, England.

Myers, S. C. D. N. S. M. (1984). Corporate financing and investment decisions when firms have information those investors do not have. Journal of financial economic, 13, 187-221. http://dx.doi.org/10.1016/0304 $-405 \mathrm{X}(84) 90023-0$ 
Sembel, R., \& Sugiharto, T. (2009). The Art of Best Win: Becoming Smarter, Tougher, Wiser and Investors. Jakarta; Elex Media Computindo-Kompas Gramedia.

Tease, W. (1993). The stock market and investment. OECD Economic Studies, 20.

Tsay, R. S. (2005). Analysis of financial time series. John Wiley and Son, New Jersey, Canada. http://dx.doi.org/10.1002/0471746193

Verbeek, M. (2004). A Guide to modern econometric. Wiley \& Sons Ltd, the Atrium, Southern Gate, Chichester, England.

\section{Copyrights}

Copyright for this article is retained by the author(s), with first publication rights granted to the journal.

This is an open-access article distributed under the terms and conditions of the Creative Commons Attribution license (http://creativecommons.org/licenses/by/3.0/). 